\title{
Cognitive rhetoric of effect: energy flow as a means of persuasion in inaugurals
}

\author{
Serhiy Potapenko \\ Nikolai Gogol State University of Nizhyn, Ukraine
}

\begin{abstract}
Cognitive rhetoric of effect deals with creating a referent's favourable image throughout four text-forming stages: invention (looking for arguments); disposition (argument arrangement); elocution (verbal ornamentation); and performance, combining the ancient canons of memory and delivery. The cognitive procedures of rhetoric of effect rest on conceptual structures of sensory-motor origin: image schemas, i.e. recurring dynamic patterns of our perceptual interactions and motor programmes (Johnson, 1987, p.xiv), and force dynamics, i.e. a semantic category in the realm of physical force generalized into domains of internal psychological relationships and social interactions (Talmy, 2000, p.409). The embedding of sensory-motor structures into the text-forming stages reveals that cognitive rhetorical effects are created by managing the energy flow, which consists of force and motion transformations denoted by particular linguistic units. The phenomenon is exemplified by the analysis of the way impressions of freedom celebration and freedom defence are formed in the inaugurals of J.F. Kennedy (1961) and G.W. Bush (2005) respectively.
\end{abstract}

\section{Key words}

cognitive rhetoric of effect, ethos, image schema, force dynamics, inaugural address

\section{Introduction}

Classical rhetoric is generally treated as a systematic and comprehensive body of knowledge primarily intended to teach public speaking (Kennedy, 2007, p.104). Since its inception rhetoric has faced two major problems concerning its object and methods. The former is presently related to persuasion (Bonnefille, 2012, p.228; Hamilton, 2003, p.356; Leith, 2012, p.1), covering a wide array of genres and media (Tabakowska, 2012, p.275), since, as Burke puts it, wherever there is persuasion, there is rhetoric (1969, p.172). In its turn, persuasion is defined as influencing the audience's mental state as a precursor to action (O'Keefe, 2007, p.595) or, in more rigorous terms, as imposition of different types of constraints on the way the audience is led to process information (Maillat and Oswald, 2013, p.137), i.e. persuasion relies on the way our mind works. As for the method, its understanding derives from seeing rhetoric as a science, a virtue, an art, a faculty, or a knack (Kennedy, 2007, p.119). On the one hand, comprehending it as an art or knack we underscore its intuitive underpinnings and restrict it to the description of what the author is trying to achieve and the strategies employed to that end (Wesley, 2014, p.136). On the other hand, Aristotle's idea of scientific rhetoric (Craig, 2007, p.140) poses it as a field with rigorous principles of influencing the addressee's mind which can be done only if we know its organization and functioning. Consequently, neither rhetoric as persuasion nor rhetoric as science is possible without the knowledge of how the human mind works. That's where cognitive rhetoric comes in: an approach independently proposed by Sperber who linked it to the mind and by Turner (1991) 
who related it to the human brain (Hamilton, 2005, p.280).

\section{Cognitive rhetoric of effect: definition}

To date, cognitive rhetoric is defined from two perspectives: ontological, i.e. that of communication participants, and epistemological, i.e. with respect to the research methods applied. Ontologically, from the sender's position, this new approach is viewed as a study of linguistic devices and strategies employed to affect the recipients' viewpoint and way of thinking (Kwiatkowska, 2012, p.9), while from the sender-receiver interaction perspective it is regarded as a study of fundamental cognitive processes at both giving and receiving ends (Tabakowska, 2012, p.276). Epistemologically, cognitive rhetoric is treated as an application of cognitive procedures to investigating persuasive means, i.e. as a study of correspondence between cognitive semantics, which seeks to understand how we generally conceptualize, imagine, and reason, and rhetorical theory, which seeks to understand how we conceptualize, imagine, and reason in particular situations (Oakley, 2005, p.455). These two sets of definitions seem to interact since authors are supposed to be aware though often intuitively - of the receivers' conceptual structures they try to affect. Therefore the integrated definition, combining ontology and epistemology, should treat cognitive rhetoric as the theory and practice of persuading explained with the application of cognitive linguistic methodology.

Currently, cognitive rhetorical studies are mainly atomistic in their nature. Leaving aside ancient teaching, they focus on separate cognitive procedures: conceptual metaphor (Hamilton, 2012, p.220), force dynamics (Oakley, 2005, p.455), image schemas (Bonnefille, 2012, p.229), conceptual integration (Gomola, 2012, p.287), Cognitive Grammar (Tabakowska, 2012, p.282). However, a comprehensive cognitive rhetorical theory seems impossible without taking into consideration the ancient techniques contributing to the persuasion process. It presupposes doing two things: first, incorporating cognitive procedures into the ancient canons of invention, disposition, elocution, memory and delivery; second, taking into account the modes of proof encompassing ethos, logos and pathos (Campbell, 2007, p.523). Amongst them logos was the first to receive its modern interpretation as a theory of argumentation (Perelman and Olbrechts-Tyteca, 1969; Van Eemeren and Grootendorst, 2004) with pathos and ethos still awaiting a contemporary rethinking. This paper argues that the development of modern media has been transforming ethos, traditionally treated as a speaker's favourable self-image (Baumlin, 2007, p.278), into rhetoric of effect aimed at creating an impression of any referent by any media understood in McLuhan's sense (1997) in any type of discourse.

The cognitive rhetoric of effect unravels the author's intended impressions, taking into consideration the conceptual structures which underlie text-formation at the stages of invention, disposition, elocution and performance, with the last one combining ancient canons of memory and delivery. Consequently, cognitive rhetoric of effect can be defined as the theory and practice of textual implementation of the author's intention, generally outlined in the introduction.

It seems natural to start the elaboration of the procedures of the cognitive rhetoric of effect with the most basic conceptual structures related to the sensory-motor experience. They include image schemas, i.e. recurring dynamic patterns of our perceptual experience by means of which we can make sense of that experience and reason about it (Johnson, 2005, p.27), and force dynamics, i.e. a fundamental semantic category that allows us to think and talk about events and relations in the physical domain as well as in epistemic and social domains (Talmy, 2000, p.209).

In this article, the procedures of the cognitive rhetoric of effect are exemplified by the analysis of inaugurals, which are central events in American political culture (Reisigl, 2010, p.252). In such speeches, the President tries to persuade his audience to believe him, to cooperate with him, to perform his plans for the future and to feel convinced that they have made the right choice (Biria and Mohammadi, 2012, p.1293).

The analysis undertaken in this paper distinguishes inaugurals' two functions: universal and specific. The universal ones, characteristic of any inaugural, include: 
unifying the audience; rehearsing communal values drawn from the past; setting forth political principles; demonstrating that the President appreciates the requirements and limitations of his executive power, urging contemplation, not action and focusing on the present while incorporating the past and the future (Campbell and Jamieson, 1986, p.235). Inaugurals' specific functions, overlooked so far, reflect a president's personal views, for example, modesty, underscored in President Obama's first inaugural (Potapenko, 2012, p.243), or personal interpretation of particular concepts, for instance, that of freedom treated from the perspectives of celebration in President John F. Kennedy's 1961 inaugural (We observe today not a victory of party but a celebration of freedom) and of defence in W. Bush's 2005 address (For a half a century, America defended our own freedom by standing watch on distant borders).

The cognitive rhetorical procedure of revealing an author's planned effects is suggested in Section 2; data analysis of implementing the specific views of freedom in J.F.K. Kennedy's inaugural and G.W. Bush's second address is provided in Section 3; a discussion of similar and specific strategies and moves applied in the speeches is offered in Section 4.

\section{Cognitive rhetoric of effect method The} suggested cognitive rhetorical procedure of revealing the effects produced by inaugurals as a type of ceremonial speech incorporates image schemas and force dynamics into four text-building canons indicating successive stages of analysis: inventional, dispositional, elocutionary and performative.

The initial - inventional - stage is aimed at reconstructing in terms of force dynamics and image schemas the canonical structure of a concept on the basis of the dictionary definitions of the nouns naming particular effects.

The difference between the employed structures of sensory-motor origin consists in the perspectives from which they portray a particular concept. Force dynamics, acknowledged as one of the main inspirations of the image schema theory (Dodge and Lakoff, 2005, p.57), draws on the notions of motion and rest to depict the internal states of both an
Agonist, i.e. the focal force, and an Antagonist, i.e. a force opposing it (Talmy, 2000 , p.410). In their turn, image schemas, initially suggested by M. Johnson (Johnson, 1987, p.116), represent a referent from four external perspectives: bodily, perceptual, moto-topological and dynamic. Bodily schemas FAR - NEAR, UP DOWN, FRONT - BACK, CENTRE PERIPHERY indicate the position of conceptualized objects relative to the human body. Perceptual schemas MASS COLLECTION - COUNT - OBJECT reflect transformations of the images of the objects which are approached or perceived from distance. Moto-topological schemas OBJECT - SURFACE / CONTACT CONTAINER - FULL / EMPTY represent motion of referents into CONTAINER or out of it. Dynamic schemas, reflecting a flow of energy, split into kinetic distinguishing the trajectories of moving objects in terms of PATH, VERTICALITY, CYCLE, and force, including COUNTERFORCE, COMPULSION, ATTRACTION, BLOCKAGE, RESTRAINT REMOVAL, DIVERSION, ENABLEMENT / DISABLEMENT (see: Potapenko, 2012, p.247).

The reconstruction of a concept on the basis of dictionary definitions yields a canonical model, reflecting the view of the majority of language speakers and serving as a criterion for distinguishing two main strategies treated as plans of practices adopted to achieve particular goals (Wodak, 2011, p.40): canonical, conforming to the reconstructed model, and non-canonical, deviating from it in the ways indicated by particular textual moves subordinating the choice of naming units.

The second - dispositional - stage is aimed at singling out the textual sections which create an intended impression. The structuring of inaugurals with the help of the traditional rhetorical scheme suggested in the Rhetorica ad Herennium (Enos and Fahnestock, 2007, p.51) seems preferable to the too-specific one outlined for inaugurals (Campbell and Jamieson, $1986, p .235$ ) and the too-general one based on the degree of displacement from the immediate here and now of a speech act (Bartlett, 2014, p.157). According to the rhetorical scheme, an inaugural should be divided into six sections: exordium, or introduction, where the mind of the 
audience is put into proper condition to receive the rest of the speech; narration, where the arguments are set out; division, where the speaker indicates what he and his opponent agree about and the areas on which they disagree; proof, where the speaker sets out his arguments; refutation, rebutting the opponents' arguments; peroration, or summing up (Enos and Fahnestock, 2007, p.51).

The third - elocutionary - stage presupposes a study of how canonical and non-canonical strategies, selected at the stage of invention, determine the choice of moves subordinating the use of naming units in separate utterances.

The fourth - performative - stage accounts for the relation of a created impression to the communication conditions of two types: macrosituational, i.e. conforming to the culture of a speaking community or the challenges facing a nation, and microsituational, i.e. represented by a particular situation of speech delivery. It is mainly the macrosituational factors that determine the personal effects created by authors of ceremonial speeches in general and of inaugurals in particular. Being a target stage, performance seems to determine the author's activity along the other phases of speech formation.

\section{Procedure of analysis}

In accordance with the outlined method the analysis of freedom celebration and defence effects in J.F.K. Kennedy's 1961 inaugural and G.W. Bush's 2005 address respectively goes through four stages: inventional, aimed at the force-dynamic and image-schematic reconstruction of the canonical structure of freedom concept; dispositional, singling out the sections and passages creating the indicated effects; and elocutionary, revealing the choice of naming units subordinated to the intended impression.

\subsection{Inventional stage}

At the stage of invention the two types of structures - force dynamics and image schemas - are applied to the conceptual reconstruction of the freedom concept whose name is defined as the right to do what you want without being controlled or restricted by anyone (LDCE, 2003, p. 641). In this definition the semantic feature 'want' indicates an Agonist's internal tendency towards motion while the feature 'without being controlled or restricted by anyone' represents that tendency externally as RESTRAINT REMOVAL, i.e. the absence of any restraint which suggests an open way or path Johnson, 1987, p.46).

This reconstruction provides three premises for further analysis. First, it offers a canonical representation of the freedom concept characterized by two tendencies: on the one hand, it is a referent's internal inclination towards motion, and on the other, it is the external condition for that motion represented by RESTRAINT REMOVAL. Secondly, these two tendencies dominating in the reconstructed model of freedom concept underlie the canonical strategy, while possible deviations represent the noncanonical strategy. Thirdly, the formation of the freedom impression can be linked not only to the noun freedom with its derivatives and synonyms but also to a wider range of units referring to RESTRAINT REMOVAL, motion or absence of hindrances.

\subsection{Dispositional stage}

A comparison of the composition of the two inaugurals at the second dispositional - stage reveals two levels of organization: rhetorical and referential. The rhetorical structure encompasses the sections of introduction (exordium), narration, division, proof, refutation and conclusion (peroration). This stage of analysis indicates that the two addresses are structured according to the modified variant of the traditional rhetorical scheme: the refutation section - rebutting the opponents' arguments - precedes the proof section where the speaker sets out his views.

The referential patterning of speeches determines the order of representing referents and their relations by particular strategies - organizing separate sections, and moves - subordinating utterances. From the referential perspective President Kennedy's canonical strategy begins by addressing the world community, successively divided into allies, new states, neighbours, adversaries, rounded off with an appeal to fellow citizens. Alternately, George W. Bush at first turns to the nation, uniting it against an adversary and then passes on to the world community and 
allies, returning to his fellow citizens in the concluding section.

\subsection{Elocutionary stage}

The elocutionary analysis reveals two interconnected tendencies in creating the impressions of freedom celebration and freedom defence. The first one concerns the ratio of explicit and implicit references to freedom with 43 direct nominations by the units free, freedom, liberty in President Bush's address and only eight cases in President Kennedy's speech. The second tendency is reflected in the direction of the energy flow creating freedom effects in terms of motion and overcoming blockage: the canonical strategy in President Kennedy's speech results in the dominance of the units evoking RESTRAINT REMOVAL and motion while the non-canonical strategy in President Bush's inaugural triggers an opposite arrangement of units and a flow of energy - from protection to motion.

\subsubsection{Freedom celebration in President Kennedy's speech}

President Kennedy's inaugural is dominated by a canonical strategy representing freedom celebration as an unhindered flow of energy in the introduction, narration and division sections, with a non-canonical one building up hindrances in the refutation, proof and conclusion sections.

The introduction (1) creates a freedom impression by superseding BLOCKAGE denoted by the noun end with different kinds of motion indicated by the units beginning, renewal and change:

(1) We observe today not a victory of party but a celebration of freedom symbolizing an end, as well as a beginning - signifying renewal as well as change.

In the narration section (2), which sets out the arguments, the idea of freedom celebration is rendered by subordinating the state (not from the generosity of the state) to God (from the hand of God) who being unaccountable to any living being occupies the highest position in the human hierarchy:

(2) And yet the same revolutionary beliefs for which our forebears fought are still at issue around the globe - the belief that the rights of man come not from the generosity of the state, but from the hand of God.

In the division section, where the speaker refers to the topics on which he agrees or disagrees with his opponents, the dynamic presentation of freedom celebration depends on the specificity of the audience addressed: the world community, poor nations, southern neighbours and the UN.

The passage addressing the world community is structured by two moves: energy release and energy emphasis.

The energy release move is implemented by units evoking two modes of RESTRAINT REMOVAL: actional, expressed by the verb let with the meaning of permission (LDCE, 2003, p.924), and perceptual, indicated by the pronoun any with semantics of nonboundedness (Westney, 1994, p.78). The link of RESTRAINT REMOVAL to freedom celebration is intensified at the end of the passage by the phrase survival and the success of liberty.

(3) Let every nation know, whether it wishes us well or ill, that we shall pay any price, bear any burden, meet any hardship, support any friend, oppose any foe, in order to assure the survival and the success of liberty.

The energy emphasis move, subordinating the five-fold combination of the pronoun we with the verb pledge, poses the speaker and his nation as an Agonist with a tendency towards motion, which is indicated by the semantic features ' $d o$ ' and 'provide' in the definition of pledge as you will definitely do or provide something (LDCE, 2003, pp.1254, 1312): This much we pledge - and more.

Portraying the USA as a worldwide champion of peace, this move is reinforced in the following passages addressing nations with different status.

In the passage meant for allies the energy emphasis move rendered by the predicate pledge is followed by the attraction move subordinating three words denoting unity: the noun loyalty, the participle united and the adjective cooperative: 
(4) To those old allies whose cultural and spiritual origins we share, we pledge the loyalty of faithful friends. United, there is little we cannot do in a host of cooperative ventures.

Depicting the prosperous countries as an Agonist with a tendency to motion, the attraction move in (4) demonstrates their power to the other nations addressed further on with the help of the energy emphasis move. It is preceded by a statement reflecting the current state of the audience addressed.

In the passage meant for the new nations (5) the energy emphasis move expressed by the phrase we pledge our word is preceded by that of restraint removal encoded by the verb welcome and followed by that of blockage for the enemies. The latter one is explicated by the combination of the negative particle not with the verb pass (shall not have passed away) denoting movement towards a more severe COMPULSION indicated by the noun tyranny with the meaning of cruel or unfair control over the people (LDCE, 2003, p. 1794):

(5) To those new States whom we welcome to the ranks of the free, we pledge our word that one form of colonial control shall not have passed away merely to be replaced by a far more iron tyranny.

In the passage addressing the poor nations (6) the blockage move expressed by the word combination the bonds of mass misery is followed by two moves depicting opportunities for this group of countries: double energy transmission and overheating. The double energy transmission move is rendered by the repetition of the verb help in the phrase to help them help portraying America as an Agonist with an increasing tendency to motion to assist the poorer nations in their struggle against misery:

(6) To those peoples in the huts and villages across half the globe struggling to break the bonds of mass misery, we pledge our best efforts to help them help themselves.[...] If a free society cannot help the many who are poor, it cannot save the few who are rich.

In addition, the termination of passage (6) with the overheating move subordinating the combination of the negative modal can with the verb save (it cannot save the few who are rich) indicates a loss of tendency to motion by wealthy countries as a collective Agonist if they fail to pass their energy surplus to the Antagonist represented by poorer nations.

In the passages addressing southern neighbours (7) and the UN (8) the move of simple energy transmission expressed by the verbs offer and assist portrays the US as an Agonist with a tendency to motion. Moreover, in (7) the result of energy transmission is underscored by a transformation of Latin neighbours into an Antagonist with a tendency to motion. The ability to overcome their misery is indicated by the phrase to cast off the chains of poverty at the end of the passage:

(7) To our sister republics south of our border, we offer a special pledge to convert our good words into good deeds - in a new alliance for progress - to assist free men and free governments in casting off the chains of poverty.

The UN is addressed in (8) by the move of single energy transmission subordinating the verb support which indicates passing energy to two targets denoted by the phrases shield of the new and the weak and area in which its writ may run:

(8) To that world assembly of sovereign states, the United Nations, our last best hope in an age where the instruments of war have far outpaced the instruments of peace, we renew our pledge of support - to prevent it from becoming merely a forum for invective - to strengthen its shield of the new and the weak and to enlarge the area in which its writ may run.

The refutation section, rebutting the opponent's arguments, opens with a noncanonical strategy of freedom defence followed by a canonical one resting on the relations of motion. 
A non-canonical strategy is implemented in (9) by a compulsion move aimed at opponents by the units request and quest, which evoke the COMPULSION image schema:

(9) Finally, to those nations who would make themselves our adversary, we offer not a pledge but a request. that both sides begin anew the quest for peace.

Further on, a non-canonical strategy evokes contrast between the moves of loss of energy and blockage. The former is implemented by the noun weakness portraying the President and his country as an Agonist with a tendency to rest while the latter is indicated by the noun arms (10) denoting means of defence:

(10) We dare not tempt them with weakness. For only when our arms are sufficient beyond doubt can we be certain beyond doubt that they will never be employed.

The blockage move is further intensified in (11) by the negation neither and the unit overburdened, indicating the upset of balance between America and its adversaries:

(11) But neither can two great and powerful groups of nations take comfort from our present course both sides overburdened by the cost of modern weapons, both rightly alarmed by the steady spread of the deadly atom, yet both racing to alter that uncertain balance of terror that stays the hand of mankind's final war.

The canonical strategy of freedom celebration organizes the second part of the refutation section by a nine-fold repetition of the structure let somebody do something, which like passage (3) represents America as a source of RESTRAINT REMOVAL by the energy release move introducing a number of initiatives: a new phase of international relations (So let us begin anew); united efforts for the sake of solving problems (Let both sides explore what problems unite us); new principles of coexistence
(Let both sides formulate serious and precise proposals); exploration of the universe (Together let us explore the stars) and freedom for the suppressed: Let both sides unite to heed in all corners of the earth the command of Isaiah - to "undo the heavy burdens [...] and to let the oppressed go free".

The proof section, addressing fellow citizens, is structured by the noncanonical strategy of freedom defence supported by compulsion and energy accumulation moves.

The compulsion move determines the use of a number of linguistic units: the two-fold repetition of the verb summon, employed impersonally; the three-fold reiteration of the noun call, evoking COMPULSION for citizens; the use of the preposition against, indicating COUNTERFORCE levelled against enemies:

(12) In your hands, my fellow citizens, more than in mine, will rest the final success or failure of our course. Since this country was founded, each generation of Americans has been summoned to give testimony to its national loyalty. Now the trumpet summons us again - not as a call to bear arms, though arms we need; not as a call to battle, though embattled we are - but a call to bear the burden of a long twilight struggle, year in and year out, "rejoicing in hope, patient in tribulation" - a struggle against the common enemies of man: tyranny, poverty, disease, and war itself. Can we forge against these enemies a grand and global alliance, North and South, East and West, that can assure a more fruitful life for all mankind?

The energy accumulation move structuring the passage about world history (13) is implemented by converging three sources of attraction denoted by the nouns energy, faith and devotion into one named by the phrase light the world at the end of the paragraph:

(13) In the long history of the world, only a few generations have been granted the role of defending freedom in its hour of maximum danger. I do not shrink from this 
responsibility - I welcome it. I do not believe that any of us would exchange places with any other people or any other generation. The energy, the faith, the devotion which we bring to this endeavor will light our country and all who serve it - and the glow from that fire can truly light the world.

The concluding part meant for American citizens is structured by two inverted compulsion moves reversing the roles of the citizens and the state (14): fellow citizens as Antagonists with a tendency to rest (ask not what your country can do for you and ask not what America will do for you) are endowed with the role of moving Agonists, which is usually expected from the state (ask what you can do for your country and what together we can do for the freedom of man):

(14) Ask not what your country can do for you - ask what you can do for your country; [...] ask not what America will do for you, but what together we can do for the freedom of man.

The inverted compulsion move concerning the world (15) equates the roles of the Agonist with the tendency to motion of both countries at large (ask of us the same high standard of strength) and of America in particular (which we ask of you):

(15) Finally, whether you are citizens of America or citizens of the world, ask of us the same high standards of strength and sacrifice which we ask of you.

To summarize, the effect of freedom celebration in President Kennedy's speech rests on a free flow of energy conforming to the canonical structure of the liberty concept which is reflected in the domination of the units denoting motion and energy transmission, while a noncanonical strategy is applied in the passages meant for adversaries and in the conclusion to compel fellow citizens' further activity.

\subsubsection{Freedom defence in President Bush's address}

The freedom defence effect in President Bush's 2005 inaugural is created by a non-canonical strategy in which virtually every passage begins with units denoting energy application or accumulation. The scene is set by the introduction (16) which underscores the intensity of force levelled against adversaries by a unification move evoking the ATTRACTION image schema. The move is rendered by the pronoun we and its derivatives in conjunction with the words unite and together.

(16) On this day, prescribed by law and marked by ceremony, we celebrate the durable wisdom of our Constitution, and recall the deep commitments that unite our country. [...] At this second gathering, our duties are defined not by the words I use, but by the history we have seen together.

The narration section is structured by three protection moves evoking corresponding image schemas with the intervention of two energy moves.

The first protection move is implemented by the phrases defended our freedom triggering the BLOCKAGE schema and break the reign of hatred and resentment denoting RESTRAINT REMOVAL, with liberty implied by the word combination force of human freedom at the end of the passage:

(17) For a half a century, America defended our freedom by standing watch on distant borders [...]. There is only one force of history that can break the reign of hatred and resentment, and expose the pretensions of tyrants, and reward the hopes of the decent and tolerant, and that is the force of human freedom.

The first intervening move of an emphasizing energy source is implemented in (18) by the noun survival, portraying freedom in the USA as an Agonist with a tendency to rest dependent on the state of global liberty. The latter is depicted as an Antagonist inclined to motion by the phrase the success of liberty. This global energy flow is 
intensified at the end of the passage by the noun expansion depicting liberty worldwide as an Agonist with a tendency to motion:

(18) The survival of liberty in our land increasingly depends on the success of liberty in other lands. The best hope for peace in our world is the expansion of freedom in all the world.

The second protection move - more intense in comparison with that in (17) - is implemented by a longer chain of units (support, defend repeated twice, force of arms, sustain, protection) positioning the USA as a BLOCKAGE source for adversaries:

(19) So it is the policy of the United States to seek and support the growth of democratic movements and institutions in every nation and culture, with the ultimate goal of ending tyranny in our world. This is not primarily the task of arms, though we will defend ourselves and our friends by force of arms when necessary. Freedom, by its nature, must be chosen, and defended by citizens, and sustained by the rule of law and the protection of minorities.

The second intervening move of simple energy transmission is rendered in (20) by the verb help depicting the US as an Agonist whose tendency to motion is passed on to the countries struggling for liberty (attain their own freedom):

(20) Our goal instead is to help others find their own voice, attain their own freedom, and make their own way.

The third protection move in (21) subordinates the verbs end and protect denoting BLOCKAGE to the phrases this nation and its people:

(21) The great objective of ending tyranny is the concentrated work of generations. [...] My most solemn duty is to protect this nation and its people from further attacks and emerging threats.
The narration section ends with an energy release move represented by the verbs to clarify and make clear evoking the RESTRAINT REMOVAL image schema which implies an open way for understanding America's position expressed by the nouns choice and success:

(22) We will persistently clarify the choice before every ruler and every nation: The moral choice between oppression, which is always wrong, and freedom, which is eternally right. [...] We will encourage reform in other governments by making clear that success in our relations will require the decent treatment of their own people.

In the final statement of (22) the energy release move is intertwined with that of simple energy transmission expressed by the verb encourage, subordinating clarification to the speaker's tendency to motion.

The refutation section, meant for the enemies of freedom, is structured by two blockage moves. The first one subordinates the verb question indicating opposition to the adversaries denoted by the pronoun some. The second one - that of double blockage - is implemented by a two-fold combination of the negation not denoting BLOCKAGE with the verb accept naming RESTRAINT REMOVAL. This move poses the President and his country as a powerful Antagonist with a tendency to motion enabling them to supersede the eternal problems of permanent tyranny and permanent slavery.

(23) Some, I know, have questioned the global appeal of liberty. [...] We do not accept the existence of permanent tyranny because we do not accept the possibility of permanent slavery.

The division section, concerning a number of addressees - the victims of tyranny, democratic reformers, rulers of outlaw regimes and leaders of totalitarian governments - opens with the noncanonical strategy of freedom defence, according to which force gradually recedes into motion underlying the idea of freedom. 
The double protection move expressed by the repetition of the phrasal verb stand for addresses those who suffer tyranny: When you stand for your liberty, we will stand with you.

The attraction move rendered by the noun leaders raises the status of democratic reformers: America sees you for who you are: the future leaders of your free country.

The double counterforce move expressed by the verb deny and the negation not warns the rulers of outlaw regimes: those who deny freedom to others deserve it not for themselves.

The motion move embodied by combining the nouns journey and progress concerns the heads of totalitarian states: To serve your people you must learn to trust them. Start on this journey of progress and justice, and America will walk at your side.

The passage addressing allies (24) tiny in comparison with that of President Kennedy's inaugural - is structured by two moves: that of energy accentuation representing America as a target of influence by the verbs honor, rely and depend and that of energy accumulation characterizing free nations by the phrase concerted effort.

(24) And all the allies of the United States can know: we honor your friendship, we rely on your counsel, and we depend on your help. [...] The concerted effort of free nations to promote democracy is a prelude to our enemies' defeat.

The proof section, addressing fellow citizens, falls into three passages concerning past, present and future. Like the previous (division) section these passages are structured by the noncanonical strategy of freedom defence with force receding into motion.

The passage concerning the past rests on opposition between two moves: energy accumulation and energy transmission. The former is rendered by the phrase accept obligations in the utterance: Our country has accepted obligations that are difficult to fulfill, and would be dishonorable to abandon. The latter, portraying America as an Agonist moving into multiple directions, is implemented by three verbs: act (we have acted in the great liberating tradition of this nation), achieve (tens of millions have achieved their freedom), reach (one day this untamed fire of freedom will reach the darkest corners of our world):

(25) Our country has accepted obligations that are difficult to fulfill, and would be dishonorable to abandon. Yet because we have acted in the great liberating tradition of this nation, tens of millions have achieved their freedom. [...] One day this untamed fire of freedom will reach the darkest corners of our world.

In the second part of the passage concerning the past (26) the energy accumulation move is reiterated by a different phrase (accept the hardest duties) with an energy transmission move rendered by the verb help underscoring the might of the speaker and his country:

\section{(26) A few Americans have accepted the} hardest duties in this cause - in the quiet work of intelligence and diplomacy [...] the idealistic work of helping raise up free governments.

The passage concerning the present characterizes the moral stand of contemporary Americans by an energy release move evoking the units related to the RESTRAINT REMOVAL schema and denoting the following features of the nation: economic independence (In America's ideal of freedom, citizens find the dignity and security of economic independence, instead of laboring on the edge of subsistence. This is the broader definition of liberty); private character (In America's ideal of freedom, the public interest depends on private character); human rights and independence (In America's ideal of freedom, the exercise of rights is ennobled by service, and mercy, and a heart for the weak. Liberty for all does not mean independence from one another). This passage is crowned with an energy transmission move (27) expressed by the phrases look after a neighbor and surround the lost, which represent rank and file Americans as Agonists whose tendency to motion is passed over to other citizens: 
(27) Our nation relies on men and women who look after a neighbor and surround the lost with love. Americans, at our best, value the life we see in one another, and must always remember that even the unwanted have worth.

The passage dealing with the future comprises two fragments structured by blockage and attraction moves with an insertion of motion moves. The blockage move in (28) is expressed by the phrase the issues and questions while the overcoming of difficulties is rendered by the motion move subordinating the verb advance in (29):

(28) From the perspective of a single day, including this day of dedication, the issues and questions before our country are many. From the viewpoint of centuries, the questions that come to us are narrowed and few.

(29) Did our generation advance the cause of freedom? And did our character bring credit to that cause?

The attraction move in (30) uniting the nation in the face of looming difficulties determines the use of the verbs unite and to be bound, which denote a precondition for further progress named by the verb to move forward subordinated to the motion move:

(30) These questions that judge us also unite us, because Americans of every party and background, Americans by choice and by birth, are bound to one another in the cause of freedom. We have known divisions, which must be healed to move forward in great purposes and I will strive in good faith to heal them.

The second attraction move is represented in (31) by the nouns unity and fellowship which denote a precondition for single energy transmission expressed by the verb to give and resulting in RESTRAINT REMOVAL named by the phrase set free:
(31) We felt the unity and fellowship of our nation when freedom came under attack, and our response came like a single hand over a single heart. And we can feel that same unity and pride whenever America acts for good, and the victims of disaster are given hope, and the unjust encounter justice, and the captives are set free.

The restraint removal move in (31) is further intensified in the concluding section by explicit and implicit motion moves concerning the future. The explicit one is rendered in (32) by the verbs go forward, move, march and the noun direction denoting movement with the nouns freedom and liberty indicating its targets:

(32) We go forward with complete confidence in the eventual triumph of freedom. [...] Not because we consider ourselves a chosen nation; God moves and chooses as He wills. We have confidence because freedom is the permanent hope of mankind. [...] When our Founders declared a new order of the ages; when soldiers died in wave upon wave for a union based on liberty, when citizens marched in peaceful outrage under the banner "Freedom Now". [...] History has an ebb and flow of justice, but history also has a visible direction, set by liberty and the Author of Liberty.

The implicit motion move generalizes in the final passage of the concluding section (33) the idea of freedom in three steps: first, it names the Liberty Bell as a symbol of freedom; second, it positions America as a source of global freedom by the verb proclaim; third, it portrays freedom as a target of the nation's further progress by the final phrase achievements in the history of freedom:

(33) When the Declaration of Independence was first read in public and the Liberty Bell was sounded in celebration, a witness said, "It rang as if it meant something." [...] America, in this young century, proclaims liberty throughout all the world. [...] 
Renewed in our strength - tested, but not weary - we are ready for the greatest achievements in the history of freedom.

To sum up, in President Bush's address the impression of freedom defence is mainly created through structuring separate sections by the moves indicating transformation of force into motion underlying the canonical representation of the freedom which results into the motto of sustaining freedom through force.

\section{Discussion}

The application of cognitive rhetorical procedures based on force dynamics and image schemas reveals that two effects peace celebration and peace defence - are implemented by canonical and noncanonical strategies determining the flow of energy in separate inaugural sections and passages, mainly reflected in the choice of naming units. An unimpeded flow of energy represented by canonical strategy dominates in President Kennedy's inaugural, rendered by units denoting motion with a gradual transformation into BLOCKAGE for opponents. Conversely, President Bush's inaugural employs a noncanonical flow of energy, as it opens with units denoting force gradually receding into motion.

Dispositional analysis reveals that the ceremonial status of the inaugurals modifies the standard rhetorical scheme of text-building: unlike the traditional model, the proof section offering the speaker's arguments crowns the addresses. Due to the knowledge of the enemy's identity the reference to freedom defence results in the specific order of President Bush's speech where the refutation section follows narration and precedes the division section.

The elocutionary choice of naming units is subordinated to strategies and moves.

The canonical strategy of peace celebration is rendered by the motion moves in the introduction and narration section of President Kennedy's address, while the impression of peace defence results in the attraction move in the introduction and three protection moves supported by energy release moves in the narration section of President Bush's inaugural.
The different effects triggered by the two inaugurals result in the specific ways of organizing the division section. In both addresses this section includes units denoting force but with a different vector. President Kennedy mainly underscores passing the nation's energy to others by moves of double and single energy transmission as well as that of overheating. Conversely, the division section in President Bush's address rests on units evoking a force vector aimed at blocking the enemy which is reflected by the moves of double protection, attraction, counterforce, gradually giving way to motion and energy accumulation.

Though occupying different positions in the two inaugurals, the refutation sections are structured by the moves of a similar (energetic) nature subordinated to a noncanonical strategy. In President Kennedy's address this section rests on units denoting compulsion, counterforce and blockage while President Bush contrasts two blockage moves.

The last but one (proof) section is structured in the two addresses by approximately similar moves. President Kennedy resorts to compulsion and energy accumulation moves while President Bush's much longer section employs energy accumulation and energy transmission moves to refer to the past, resorting to the energy unleashing move depicting the present and uses the attraction move anticipating the future.

The concluding sections in both addresses employ moves differing from the overall strategies structuring the body of the texts: President Kennedy relies on an inverted compulsion move mitigating a force impression while President Bush employs explicit and implicit motion moves turning to the canonical portrayal of freedom.

This comparison reveals that the persuasive potential of the two inaugurals rests on various transformations of energy potential revealed by strategies and moves, which paves the way for further studies of ceremonial speeches.

\section{Conclusion}

As for the object and methods of rhetoric, the undertaken analysis yields two outcomes. First, the application of sensory-motor structures to exposing the nature of persuading, treated as changing 
the addressee's mental state and imposing varying types of constraints on information processing, reveals that this impact is achieved by changing the flow of energy indicated by units with the meaning of force and motion. Secondly, the conceptual structures employed in the study offer the rigour necessary for the development of rhetoric as a science. Hence, the emerging cognitive rhetoric of effect going back to ethos can be treated as a scientific approach to an ancient field.

\section{References}

BARTLETT, T., 2014. Analysing power in language. London: Routledge.

BAUMLIN, J., 2007. Ethos. In: Th. Sloane, ed. Encyclopedia of rhetoric. Oxford: Oxford University Press, pp. 278-292.

BIRIA, R. and MOHAMMADI, A., 2012. The sociopragmatic function of inaugural speech: $A$ critical discourse analysis approach. Journal of Pragmatics, vol. 44, pp. 1290-1302.

BONNEFILLE, S., 2012. Obama's and Sarkozy's remarks at the U.N.'s Climate Change summit: A contest between figurative and literal language?" In: A. Kwiatkowska, ed. Texts and minds: Papers in cognitive poetics and rhetoric. Frankfurt am Main: Peter Lang, pp. 225-243.

BURKE, K., 1969. A rhetoric of motives. California: University of California Press.

CAMPBELL, K. K., 2007. Modern rhetoric. In: Th. Sloane, ed. Encyclopedia of rhetoric. Oxford: Oxford University Press, pp. 517-527.

CAMPBELL, K. K. and JAMIESON, K. H., 1986. Inaugurating the presidency. In: H. Simons, A. Aghazarian, eds. Form, genre, and the study of political discourse. Columbia: University of South Carolina Press, pp. 203-225.

CRAIG, R., 2007. Communication. In: Th. Sloane, ed. Encyclopedia of rhetoric. Oxford: Oxford University Press, pp. 125-146.

DODGE, E. and Lakoff, G., 2005. Image schemas: From linguistic analysis to neural grounding. In: B. Hampe, ed. From perception to meaning: Image schemas in cognitive linguistics. Berlin, N.Y: Mouton de Gruyter, pp. 57-92.

ENOS, R. L. and Fahnestock, J., 2007. Arrangement. In: Th. Sloane, ed. Encyclopedia of rhetoric. Oxford: Oxford University Press, pp. 49-53.

GOMOLA, A., 2012. Cognitive mechanisms at work and their perlocutionary effect in Catholic preaching. A case study. In: A. Kwiatkowska, ed. Texts and minds: Papers in cognitive poetics and rhetoric. Frankfurt am Main: Peter Lang, pp. 287-298.

HAMILTON, C., 2003. Genetic Roulette: On the cognitive rhetoric of biorisk. In: R. Dirven, R. Frank, M. Pütz, eds. Cognitive models in language and thought. Berlin: Mouton de Gruyter, pp. 353-393.

HAMILTON, C., 2005. A cognitive rhetoric of poetry and Emily Dickinson. Language and Literature, vol. 14, pp. 279-294.

HAMILTON, C., 2012. Tony Blair's cognitive rhetoric. In: A. Kwiatkowska, ed. Texts and minds: Papers in cognitive poetics and rhetoric. Frankfurt am Main: Peter Lang, pp. 201-225. JOHNSON, M., 1987. The body in the mind: The bodily basis of meaning, imagination, and reason. Chicago: The University of Chicago Press.

JOHNSON, M., 2005. The philosophical significance of image schemas. In: B. Hampe, ed. From perception to meaning: Image schemas in cognitive linguistics. Berlin: Mouton de Gruyter, pp. 15-34.

KENNEDY, G., 2007. Classical rhetoric. In: Th. Sloane, ed. Encyclopedia of rhetoric. Oxford: Oxford University Press, pp. 104-125.

KWIATKOWSKA, A., 2012. From the editor. In: A. Kwiatkowska, ed. Texts and minds: Papers in cognitive poetics and rhetoric. Frankfurt am Main: Peter Lang, pp. 7-10.

LEITH, S., 2012. You talkin' to me? London: Profiles Books.

LDCE., 2003. Longman dictionary of contemporary English. Harlow: Longman.

MAILLAT, D. and OSWALD, S., 2013. Editorial. Biases and constraints in communication: Argumentation, persuasion and manipulation. Journal of Pragmatics, vol. 59, pp. 137-140.

MCLUHAN, M., 1997. Understanding media: The extensions of man. Cambridge (Mass.): The MIT Press.

OAKLEY, T., 2005. Force-dynamic dimensions of rhetorical effect. In: B. Hampe, ed. From perception to meaning: Image schemas in cognitive linguistics. Berlin, N.Y.: Mouton de Gruyter, pp. 444-473. 
O'KEEFE, D., 2007. Persuasion. In: Th. Sloane, ed. Encyclopedia of rhetoric. Oxford: Oxford University Press, pp. 595-603.

PERELMAN, Ch. and OLBRECHTS-TYTECA, L., 1969. The New rhetoric: A treatise on argumentation. Notre Dame: University of Notre Dame Press.

POTAPENKO, S., 2012. Modest or determined? Cognitive-rhetorical analysis of the effects of President Obama's inaugural and congressional speech. In: A. Kwiatkowska, ed. Texts and minds: Papers in cognitive poetics and rhetoric. Frankfurt am Main: Peter Lang, pp. 243-258. REISIGL, M., 2010. Rhetoric of political speeches. In: R. Wodak, V. Koller, eds. Handbook of communication in the public sphere. Berlin: Mouton de Gruyter, pp. 243-269.

TABAKOWSKA, E., 2012. Rhetoric: "the most valuable gift of gods" or "the art of deception"? In: A. Kwiatkowska, ed. Texts and minds: Papers in cognitive poetics and rhetoric. Frankfurt am Main: Peter Lang, pp.273-286.

TALMY, L., 2000. Force dynamics in language and cognition. Concept structuring systems. vol. 1. Cambridge (Mass.): The MIT Press,

TURNER, M., 1991. Reading minds: The study of English in the age of cognitive science. Princeton: Princeton University Press.

VAN EEMEREN, F. and GROOTENDORST, R., 2004. A systematic theory of argumentation: The pragma-dialectical approach. Cambridge: Cambridge University Press.

WESLEY, J., 2014. The qualitative analysis of political documents. In: K. Bertie, I. Maks, A. van Elfrinkhof, eds. From text to political position: Text analysis across disciplines. Amsterdam, Phil.: John Benjamins Publishing Company, pp.135-159.

WESTNEY, P., 1994. Rules and pedagogical grammar. In: T. Odlin, ed. Perspectives on pedagogical grammar. Cambridge: Cambridge University Press, pp. 72-96.

WODAK, R., 2011 . The discourse of politics in action. Basingstoke: Palgrave Macmillan.

Author's address and contact details

Professor Dr. Serhiy Potapenko

Nikolai Gogol State University of Nizhyn

16604, Nizhyn, Chernihiv Oblast

Ukraine

E-mail: potapenko.sergey@mail.ru 